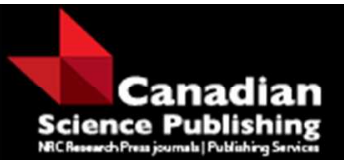

Canadian Journal of Forest Research Revue canadienne de recherche forestière

\title{
Intracone variation explains most of the variance in Picea abies seed weight: implications for seed sorting
}

\begin{tabular}{|r|l|}
\hline Journal: & Canadian Journal of Forest Research \\
\hline Manuscript ID & cjfr-2015-0379.R1 \\
\hline Danuscript Type: & Article \\
\hline Complete List of Authors: & $\begin{array}{l}\text { Himanen, Katri; Natural Resources Institute Finland, } \\
\text { Helenius, Pekka; Natural Resources Institute Finland } \\
\text { Ylioja, Tiina; Natural Resources Institute Finland } \\
\text { Nygren, Markku; Natural Resources Institute Finland }\end{array}$ \\
\hline Keyword: & Cone insect, Norway spruce, radiography, seed orchard, stand seed \\
\hline & \\
\hline
\end{tabular}

\section{SCHOLARONE ${ }^{m}$}

Manuscripts 
1 Katri Himanen $^{\mathrm{a}, *}$, Pekka Helenius $^{\mathrm{a}}$, Tiina Ylioja $^{\mathrm{b}}$ \& Markku Nygren ${ }^{\mathrm{a}}$

2

3 Intracone variation explains most of the variance in Picea abies seed

4 weight: implications for seed sorting

5

6 a Natural Resources Institute Finland, Suonenjoki Unit, Juntintie 154, FI-77600 Suonenjoki,

$7 \quad$ Finland

8 b Natural Resources Institute Finland, Vantaa Unit, Jokiniemenkuja 1, FI-01370 Vantaa,

$9 \quad$ Finland

10

$11 *$ Corresponding author

12 e-mail: katri.himanen@luke.fi

13 tel: +358295325276

14

15 Co-author e-mails

16 pekka.helenius@1uke.fi

17 tiina.ylioja@,luke.fi

18 markku.nygren@1uke.fi

19

20

21

22 


\section{Abstract}

27 Norway spruce seed is collected from both forest stands after final felling and from seed orchards. To produce high-germinability seed lots easy to use in nursery sowing machines, empty, insect-damaged, and other poor-quality seeds are culled. Sorting is done typically by weight or size. Previous studies of conifer seed have indicated wide variation in seed weight

31 between individual trees or clones. However, the intratree or intraclone variation has rarely

32 been taken into account, and intracone variation in seed weight has not been examined. We collected cones from a forest stand and from a clonal seed orchard in central Finland. Each seed from each cone was extracted, weighed, x-rayed to assess their quality. Trees and clones differed in terms of the proportions of different quality seed. Variance component analysis showed that the intracone variation explained a larger proportion of the total variation in seed weight than did the intercone or intertree, or interclone variation. Thus weight-based seed sorting has less effect on the genetic diversity of a seed lot than previously believed. We also conclude that the large differences in proportion of full seed among trees and clones impact the contribution of genotypes in seed and eventually seedling lots.

\section{Keywords}

44 Cone insect, Norway spruce, radiography, seed orchard, stand seed 
50

51

52

\section{Introduction}

In Finland, approximately $1100 \mathrm{~kg}$ of Norway spruce (Picea abies (L.) H. Karst.) seed is used annually in nurseries to produce seedlings for forest regeneration. Recently (2002-2012), 15$78 \%$ of this has originated from seed orchards (Finnish Statistical Yearbook 2013). The role of genetically improved forest regeneration material is more prominent in the other Nordic countries, but in general seed collections from forest stands after final felling still play a substantial role in seedling production of Norway spruce in Northern Europe (Mullin et al. 2011; Swedish Statistical Yearbook of Forestry 2014). This also holds true for many other conifer species with economic importance.

Conifer seeds are sorted after seed extraction and seed wing removal to discard empty, insectinfested, and damaged seed, that would otherwise reduce the germination capacity of a seed lot. Sorting is usually done by sieves, gravity tables, and blowers (Kolotelo et al. 2001; Karrfalt 2008). The former sorts seeds by size and the latter two mostly by weight. Light weight as well as the largest seeds are often removed to ensure proper functioning of sowing machines in nurseries.

Seed weight can also affect the germination rate. Sorenson and Campbell (1993) reported faster germination in heavy Douglas-fir (Pseudotsuga menziesii (Mirb.) Franco) seeds than in lighter seeds, as did Dunlap and Barnett (1983) in a study of Scots pine (Pinus sylvestris L.). Seed weight also correlates positively with seedling size in conifers (Dunlap and Barnett 1983; Reich et al. 1994), although the effect is typically temporary (Mikola 1980; Sorenson and Campbell 1993). 
74 The main storage tissue of conifer seeds, the megagametophyte, which comprises the major

75 part of the seed weight, is haploid maternal tissue (Reich et al. 1994). Therefore, there is a

76 genetic relationship between the mother tree and seed weight (Roach and Wulff 1987; Castro

77 1999). In several conifer species, including Norway spruce, individual trees or clones in a seed orchard produce seed of varying weight (Andersson 1965; Hellum 1976; von Weissenberg 1981; Lindgren 1982; Stoehr and Farmer 1986; Clair and Adams 1991;

80 Chaisurisri et al. 1992; Matziris 1998; Glynn and Weslien 2004). In addition to a genetic 81 component, seed weight is affected by the temperature sum of the ripening year. Therefore seed weight differs among years in the same location (Sorensen and Franklin 1977; Borgman et al. 2014) and in general the lightest seeds originate from the northern and the heaviest seeds from the southern latitudes in the Northern Hemisphere (Khalil 1986). The nutritional status of the mother plant also affects the seed weight (Bazzaz et al. 2000; Karlsson and genotypes in a given seed lot.

Previous studies of the effect of genotype on seed weight in conifer seed lots have been done by bulking together the cones from individual trees or clones (Andersson 1965; Hellum 1976; von Weissenberg 1981; Lindgren 1982; Stoehr and Farmer 1986; Clair and Adams 1991; Chaisurisri et al. 1992; Matziris 1998; Glynn and Weslien 2004). The effect of maternal genotype on seed weight has been assessed by measuring all seed in the bulk samples or by taking subsamples from these, with the result that the seed weight is determined by the mother tree. However, this approach does not take into account the variation in seed weight within a tree or within an individual cone. It is, in fact, unclear how much variation in seed weight is explained by intratree factors in comparison to genotypic maternal variation. 
99 In this study, we considered the following: (i) does there exist genotypic maternal (intertree

100 or interclone) variation in seed quality, (ii) how much variation in seed weight is explained by intertree/graft, intercone and intracone variation, and (iii) is the variation in seed weight in a forest stand similar to that in a seed orchard? With this information, we aimed to assess the effect of weight-based sorting on the genetic base of Norway spruce seed lots.

\section{Material and Methods}

\subsection{Cone collection in a forest}

108

Cones of seven randomly chosen individual trees were collected from a mature, naturally formed Norway spruce dominated stand in Kuopio (Puijo Hill), central Finland (62 $54^{`} \mathrm{~N}$, 27³9’E), 190-215 m above sea level (a.s.1), on March 14, 2011 (Table 1). The seven trees were located at a range of $470 \mathrm{~m}$. The site is a fertile Oxalis-Myrtillus-type forest, with an average temperature sum (baseline temperature $+5^{\circ} \mathrm{C}$ ) of 1300 degree days (d.d.) and annual precipitation of 549 mm (years 1981-2010 in Kuopio; 10 x 10 km data; Venäläinen et al. 2005). In the year of seed maturation (2010) the temperature sum in Kuopio was 1522 d.d. and the precipitation $570 \mathrm{~mm}$.

118 Ten liters of cones were collected from the tree crowns of each tree with a boom lift. Cones

119 were collected from three points, i.e. from different side and height, in each crown to get a representative sample. Cones with clear rust infection or visible insect damage were not collected. Tree height and diameter at breast height were measured at the site. A core sample was drawn from each of the trees at breast height by an increment borer and the age of the trees was counted from the tree rings. 
124 Of the cones collected, three from each tree were drawn randomly for water content analysis.

125 By measuring the water content we ensured that the seed development had been completed 126 normally and that our seed samples were thus representative. The water content of the cones

127 was measured from one fourth of each of these cones (cones cut along both length and width)

128 on a fresh weight basis, using constant temperature oven method $\left(103{ }^{\circ} \mathrm{C}, 17 \mathrm{~h}\right)$ (International

129 Seed Testing Association 2007). A minimum on 50 seeds were removed from the rest of each

130 cone, and the water content of the seeds was measured similarly. The mean water content of

131 both cones and seeds for each tree was counted as the average of the three cones measured.

132

\subsection{Cone collection in a seed orchard}

The cones of five clones - from one graft in each clone - were collected from a first generation Norway spruce seed orchard in Joroinen, in central Finland (Sv403 Suhola 1, $62^{\circ} 15^{\prime} \mathrm{N}, 27^{\circ} 42^{\prime} \mathrm{E}, 90 \mathrm{~m}$ a.s.l.) on January 14, 2013 (Table 2). The orchard was established in 1994 on old agricultural land with 35 different clones at a density of 360 grafts per hectare. The total area of the seed orchard is 4.7 ha and the average height of the grafts at the time of cone collection was $9.5 \mathrm{~m}$. The grafts in the seed orchard were originally to be planted in a more southerly location in Finland. The plus trees from which the grafts originate are located approximately $2^{\circ}$ south (latitude) and from 100-200 d.d. warmer conditions than where the orchard is located. The average temperature sum in Joroinen is 1260 d.d. and mean

144 precipitation $563 \mathrm{~mm}$ (years 1981-2010; 10 x $10 \mathrm{~km}$ data; Venäläinen et al. 2005). In the year of seed maturation (2012), the temperature sum in Joroinen was 1297 d.d. and precipitation $737 \mathrm{~mm}$. Two liters of cones were collected from each graft. The cone and seed water contents were measured as described for cones collected from the forest stand. 
150

151

152

153

154

\subsection{Seed extraction, measurement, and evaluation}

After the collection and water content measurements, the cones were cleaned of debris (twigs and needles) and stored at $-15{ }^{\circ} \mathrm{C}$. Five cones from each stand tree and four cones of each orchard clone were selected for seed extraction. When the seeds were extracted, the cones were allowed to thaw at room temperature, after which they were placed individually in paper envelopes to a heating cabinet at $38^{\circ} \mathrm{C}$. The cones were kept in the cabinet until the cone scales opened completely, for $24 \mathrm{~h}$ at the most. Every seed was extracted; those that did not fall out of the cones were removed with tweezers. The seed wings were removed carefully by hand and the seeds placed on an adhesive film in a cardboard frame so that each seed could be monitored. The seeds were then x-rayed (Faxitron MX-20; Faxitron Bioptics LLC, AZ, USA; CEA orthochromatic mammography film, Agfa Healthcare NV, Mortsel, Belgium, exposure $18 \mathrm{kV}, 4 \mathrm{~s}$ ) to evaluate their quality.

The seeds were classified as 1) full (the megagametophyte fills the seed coat and the embryo fills the embryo cavity), 2) anatomically immature (the megagametophyte and / or the embryo do not entirely fill the seed coat or the embryo cavity), 3) severely anatomically immature (the megagametophyte fills less than $60 \%$ of the seed coat and / or embryo is missing or shorter than $50 \%$ of the total length of the seed), 4) development stagnated (the megagametophyte and embryo development have commenced but stopped, creating dried remnants of these tissues), 5) empty (seed coat entirely empty or only remnants of membrane tissue are visible), 6) larvae-infested, 7) insect damaged, 8) mechanically damaged, or with 9) unidentifiable damage (Fig.1). The insect species inside the seed were identified according to Simak (1955) and Wiersma (1973). The seeds, still attached to the frames, were placed in cabinets (Vötsch VCL 0003; Vötsch Industrietechnik GmbH, Balingen Germany) at $20{ }^{\circ} \mathrm{C}$ 
174 and relative humidity of $35 \%$ for at least $48 \mathrm{~h}$ prior to weighing each seed individually

175 (Mettler-Toledo MT5 microscale; Mettler-Toledo, Greifensee, Switzerland).

176

177

\subsection{Statistical analysis}

178

179 To compare the proportions of different quality seeds tree-wise, a generalized linear model, 180 using a logit link function, was fitted separately for each seed quality class. Tree or clone was taken as a fixed effect. Due to correlated structure of the data, an overdispersion parameter was estimated so as not to underestimate parameter standard errors and p-values. The logit model was:

184

$\operatorname{logit}\left(\mathrm{p}_{i}\right)=\mathrm{b}_{o}+\mathrm{b}_{1} \mathrm{~T}_{1 i}$

where logit $\left(\mathrm{p}_{i}\right)$ is the proportion of a given quality class in each tree; $\mathrm{b}_{o}$ is the intercept; $\mathrm{T}_{i}$ is the $i$ th tree effect.

Individual model terms (including an overdispersion parameter) were assessed by comparing the log-likelihood of two nested, candidate models as well as the Akaike information criterion and Wald-significance test for parameter coefficients.

194 The seed weight data were analyzed with linear mixed model to estimate and partition the total random variability between and within individual trees and cones. In this analysis, the tree and cone effects were considered as random. The variance component model was: 
199 where $\mathrm{y}_{i j k}=$ observation on seed $k$ in cone $j$ in tree $i ; \mu$ is the intercept; $\mathrm{a}_{i}$ is the random tree 200 effect; $b_{i j}$ is the random cone effect, and $\mathrm{e}_{i j k}$ is the random seed effect.

201

202

In separate analyses, the differences in seed weight between trees and clones were analyzed also with a linear mixed model, but here tree or clone was taken as a fixed factor for tree-wise comparison. The fixed model terms were considered statistically significant at $p \leq 0.05$. For the analyses, we used GenStat 15 software (VSN International Ltd, Hemel Hempstead, UK)

206 (VSN International 2012).

3 Results

3.1 Seed quality

The cone water content was under $30 \%$ in all samples and the seed water contents were still lower (Tables 1 and 2). The proportion of full seed varied among the individual trees of the forest stand (Table 3). The cones of tree no. 1 had less than 30\% full seed, while trees no. 5 and 6 had approximately $85 \%$. Spruce seed chalcid (Megastigmus strobilobius Ratzeburg) larvae-infested and spruce seed moth (Cydia strobilella $(\mathrm{L}$.$) ) damaged seeds were found on$ all trees in small numbers. Spruce seed gall midge (Plemeliella abietina Seitn.) infested seeds were present in three trees out of seven. Developmentally stagnated seeds were observed in 219 five trees.

In addition to the proportions of full seed, the percentage of empty and spruce seed chalcid infested seed showed wide variation between the mother trees; e.g. in the latter, the 
224 proportions of full, empty, immature, and spruce seed chalcid-infested seed, as well as seed

225 with spruce seed moth damage and with development stagnated varied in a statistically 226 significant manner between trees (Table 3).

228 In the material collected from the seed orchard, the differences in proportions of full and 229 empty seeds between clones were statistically significant as well (Table 4): Clone E1549 230 produced only $33.2 \%$ full seed, which is notably less than in the others. In contrast to the seed

231 from the forest stand, spruce seed chalcid and spruce seed gall midge infested seeds were 232 completely absent in the orchard cones, while spruce seed moth damage was more common.

\subsection{Seed weight}

When the seed weights between individual trees or clones were compared, statistically significant differences were present in all major quality classes (Tables 5 and 6). In the stand seed, tree no. 3 produced the lightest and tree no. 7 the heaviest full seed. The average seed weights of full seed in the orchard material also varied by over $1 \mathrm{mg}$ between the lightest and heaviest clones. In addition, the total ranges of seed weights, considering the seed from all quality classes, were different between trees and clones (Figs. 2 and 3).

However, examination of the source from which seed weight variation derived from, revealed that the intracone variation was larger than that between cones, or between trees or clones 245 (Tables 7 and 8). Variance component analysis showed that the intracone variation explained $85.1 \%$ of the total variance of seed weight in the stand seeds. Examination of full seed with mass greater than $2.5 \mathrm{mg}$ revealed that the intracone variation accounted for $53.0 \%$ of total variance in seed weight and intertree variance accounted for $28.6 \%$. 
249 In analyzing all the orchard seed material, the intracone variation accounted for $80.2 \%$ of the 250 total variation in seed weight. Analysis of only full seed with mass greater than $2.5 \mathrm{mg}$ 251 showed that the intracone variation explained $51.7 \%$ and the interclone variation $24.3 \%$ of 252 the total variation.

\section{Discussion}

\subsection{Seed quality and insect damage}

257

Both the cone and seed water levels were indicative of normal maturation in both the stand and seed orchard material (Tables 1 and 2). Seed quality, especially the proportion of full seed, varied among individual trees and clones (Tables 3 and 4). In trees or clones with low numbers of full seed, the proportion of empty seed was, in contrast, large. This indicates that either pollination or fertilization was unsuccessful in certain genotypes. The susceptibility of the female strobili of these genotypes may have been non-synchronous with the peak pollen dispersal, but this is speculative, since no observations on the flowering phenology of the trees and grafts were conducted. Our results concur with studies in which the uneven contribution of genotypes in conifer seed crops is well documented (Eriksson et al. 1973; Byram et al. 1986; Stoehr and Farmer 1986; Saarsalmi et al. 1994; Nikkanen and 268 Ruotsalainen 2000).

Sampling of the cones for the study cannot be considered random with regard to insect damage, sincecones with cone rust infestation and clear external signs of insect damage were 
273 seed chalcid and spruce seed gall midge are not visible on the surface of the cone. Therefore

274 the results on their frequency can be counted as reliable.

275

276 Spruce seed moth damage was more common in the seed orchard than in the stand seed. The

277 study material was collected in different years (2011 and 2013), which may explain the

278 difference: spruce seed moth populations fluctuate annually (Annila 1981). Since the

279 collection sites are approximately $90 \mathrm{~km}$ apart, spatial variation in insect population density

280 can also be expected. In addition, the difference may have been related to the seed production

281 environment (stand vs. orchard), although our study material was from one stand and from

282 one orchard only. In the forest stand, the proportion of spruce seed moth- damaged seed

283 differed in a statistically significant manner among the trees. Glynn and Weslien (2004) also

284 reported a genotypic effect on the infestation rate of spruce seed moth in Norway spruce.

285 However, in our seed orchard material, no statistically significant differences were observed

286 among the clones.

287

288 Rosenberg et al. (2012) reported that as the number of spruce seed chalcid-infested seed in

289 Norway spruce cones increased, seed weight decreased. Our findings do not support this. In

290 the stand material, tree no. 4 showed the highest proportion of spruce seed chalcid-infested

291 seed, but it also contained the heaviest full seed (Tables 3 and 5). The average full seed

292 weight also showed similar variation in the orchard material as in stand seed, although no

293 seed chalcids were found in the orchard seed.

294

295

4.2 Seed weight

296 
297 Previous studies in conifers have shown that seed weight is dependent on the mother tree 298 (Hellum 1976; Lindgren 1982; von Weissenberg 1981; Stoehr and Farmer 1986; Clair and 299 Adams 1991; Matziris 1998). This is explained to be due to the large proportion of maternal 300 tissue in conifer seed and also due to environmental factors, such as nutrient availability, 301 being mediated by the mother tree (Clair and Adams 1991).

303 Examination of the average weights, e.g. of full seed, revealed that statistically significant 304 differences among trees and clones were present in our material as well (Tables 5 and 6). 305 However, analyzing the source of variation in seed weight - either of all seed or full seed 306 showed that the maternal effect is not the most important factor (Tables 7 and 8), because the 307 intracone variation in seed weight was larger than that between trees or clones, or between several cones.

312 It is also notable that the proportions of the variation components were similar in both the stand and orchard material (Tables 7 and 8). This suggests that the effect on seed weight from the different sources of variation was not a random phenomenon or dependent on the environment. Due to the limited number of mother trees and data from one year only in the present study, further evidence is needed to confirm this. It must also be noted that the study material was collected from a first generation orchard. This can be a source for the similarity between results in stand and orchard material. Our results apply when sorting is done on weight basis only. Although seed weight and seed size are strongly correlated, they should not be used as synonyms. Although various conifer taxa share traits with regard to seed weight, the applicability of our results to other conifers species needs to be confirmed. 
324 The maintenance of forest genetic resources is paramount for adaptation to climate change and other environmental changes and for forest ecosystem functioning (Alfaro et al. 2014). Forest management practices, including many steps in forest regeneration significantly impact genetic diversity of forest trees (Ratnam et al. 2014) and therefore care must be taken in composing seed material for regeneration.

Our results give reason to re-evaluate current conceptions on the weight-based sorting of lack seed from certain mother trees also according to present data, indicating that these extreme fractions are genetically narrow and should not be used as regeneration material alone. However, since sorting begins with all the seed extracted from the cones, the sorting effect on the genetic diversity of the main seed lot is far less dramatic.

As the present data show, not all maternal genotypes contribute equally to the pool of full seed via their different proportions of them. We did not determine the number of cones produced by each tree or graft and therefore cannot assess the actual contribution of individual trees or clones to the entire full seed production of the stand or seed orchard.

342 However, we know that both the abundance of flowering, as well as the amount of full seed, vary on a yearly basis in Norway spruce (Eriksson et al. 1973; Nikkanen and Ruotsalainen 2000). The effect of this phenomenon to genetic diversity is counteracted in seed orchards by using sufficient numbers of clones. The current results emphasize the need for this. In a natural forest stand, the non-uniform contribution of each mother tree would be evened out 
347 by this yearly variation, since the new stand is not a result of seed from a single year. In 348 contrast, the seed and eventually seedling lots in artificial forest regeneration present a snap 349 shot of this continuum, including the genetic variation of just one year. proportions.

Based on this study seed sorting is not the main culprit in narrowing of genetic diversity by exclusion of certain maternal genotypes, but we should instead take into account the natural processes occuring in Norway spruce seed production. As shown in this and previous studies (Eriksson et al. 1973; Saarsalmi et al. 1994), yearly variation in the genetic construction of seeds produced in a seed orchard is so large that it may be necessary to take this also into account in planning seed use maps, guidelines for seed transfer and in determining the sufficient number of clones in new seed orchards. 


\section{Acknowledgements}

373

374 We thank Sirpa Kolehmainen and Mervi Ahonpää for their gracious assistance in gathering

375 the study material. Seppo Ruotsalainen is acknowledged for valuable comments to the

376 manuscript. The study was financially supported by Graduate School in Forest Sciences

377 (GSForest), Metsämiesten säätiö Foundation and Metsänjalostussäätiö Foundation.

\section{References}

Alfaro, R.I., Fady, B., Vendramin, G.G., Dawson, I.K., Fleming, R.A., Sáenz-Romero, C., Lindig-Cisneros, R.A., Murdock, T., Vinceti, B., Navarro, C.M., Skrøppa, T., Baldinelli, G., El-Kassaby, Y.A. and Loo, J. 2014. The role of forest genetic resources in responding to biotic and abiotic factors in the context of anthropogenic climate change. For. Ecol. Manage. 333: 76-87. doi: 10.1016/j.foreco.2014.04.006

Andersson, E. 1965. Cone and seed studies in Norway spruce (Picea abies (L.) Karst.). Stud. For. Suec. Nr 23. 214 p.

Annila, E. 1981. Fluctuations in cone and seed insect populations in Norway spruce.

Commun. Inst. For. Fenn. 32 pp.

Bazzaz, F.A., Ackerly, D.D. and Reekie, E.G. 2000. Reproductive allocation in plants. In: Fenner, M. (Ed.). 2000. Seeds: the ecology of regeneration in plant communities. $2^{\text {nd }}$ edition. CABI Publishing, New York, NY, USA. pp. 1-29. 
Borgman, E.M., Schoettle, A.W. and Angert, A.L. 2014. Using among-year variation to assess maternal effects in Pinus aristata and Pinus flexilis. Botany 92(11): 805-814. doi: $10.1139 / \mathrm{cjb}-2014-0085$

Byram, T.D., Lowe, W.J. and McGriff, J.A. 1986. Clonal and annual variation in cone production in loblolly pine seed orchard. For. Sci. 32(4): 1067-1073.

Castro, J. 1999. Seed mass versus seedling performance in Scots pine: a maternally dependent trait. New Phytol.144: 153-161. doi: 10.1046/j.1469-8137.1999.00495.x

Chaisurisri, K., Edwards, D.G.W. and El-Kassaby, Y.A. 1992. Genetic control of seed size and germination in Sitka spruce. Silvae Genet. 41(6): 348-355.

Clair, J.B. and Adams, W.T. 1991. Effects of seed weight and rate of emergence on early growth of open-pollinated Douglas-fir families. For. Sci. 34(4): 987-997.

Dunlap, J.R. and Barnett. J.P. 1983. Influence of seed size on germination and early development of loblolly pine (Pinus taeda L.) germinants. Can. J. For. Res. 13(1): 40-44. Eriksson, G., Jonsson, A. and Lindgren, D. 1973. Flowering in a clone trial of Picea abies Karst. Stud. For. Suec. Nr 110. 49 p.

Finnish Statistical Yearbook of Foresty. 2013. Official Statistics of Finland. Agriculture, Forestry and Fishery. Finnish Forest Research Institute. 450 p. 
Glynn, C. and Weslien, J. 2004. Bacillus thuringiensis variety kurstaki x aizawai applied to spruce flowers reduced Dioryctria abietella (Lepidoptera: Pyralidae) infestation without affecting seed quality. J. Econ. Entomol. 97(6): 1836-1841. doi:

http://dx.doi.org/10.1093/jee/97.6.1836

Hellum, A.K. 1976. Grading seed by weight in white spruce. TPN 27(1): 16-17, 23-24.

International Seed Testing Association. 2007. ISTA handbook on moisture determination, $1^{\text {st }}$ edition. International Seed Testing Association. Bassersdorf, Switzerland.

Karlsson, C. and Örlander, G. 2002. Mineral nutrients in needles of Pinus sylvestris seed trees after release cutting and their correlations with cone production and seed weight. For. Ecol. Manage. 166: 183-191. doi: 10.1016/S0378-1127(01)00684-3

Karrfalt, R.P. 2008. Seed harvesting and conditioning. In: Bonner, FT. \& Karrfalt, RP. (Eds.). 2008. The woody plant seed manual. United States Department of Agriculture, Forest Service. Agricultural Handbook 727. pp. 57-84.

Khalil, M.A.K. 1986. Variation in seed quality and some juvenile characters in white spruce (Picea glauca (Moench) Voss). Silvae Genet. 35(2-3):78-85.

Kolotelo, D., Van Steenis, E., Peterson, M., Bennett, R., Trotter, D. and Dennis, J. 2001. Seed handling guidebook. British Columbia. Ministry of Forest. Tree Improvement Branch. 151 p. 
Lindgren, D. 1982. Fractionation of seed orchard seeds by weight does have genetic implications. Silva Fenn. 16(2): 156-160.

Matziris, D. 1998. Genetic variation in cone and seed characteristics in a clonal seed orchard of Aleppo pine grown in Greece. Silvae Genet. 74(1): 37-41.

Mikola, J. 1980. The effect of seed size and duration of growth on the height of Scots pine (Pinus sylvestris L.) and Norway spruce (Picea abies (L.) Karst.) provenances and progenies at the nursery stage. Silva Fenn. 14(1):84-94.

Mullin, T.J., Andersson, B., Bastien, J.-C., Beaulieu, J., Burdon, R.D., Dvorak, W.S., King, J.N., Kondo, T., Krakowski, J., Lee, S.J., McKeand, S.E., Pâques, L., Raffin, A., Russell, J., Skrøppa, T., Stoehr, M., and Yanchuk, A. 2011. Economic importance, breeding objectives and achievements. In Genetics, Genomics and Breeding of Conifers. Edited by C Plomion, J. Bousquet, and C. Kole. Science Publishers, Enfield, NH. pp. 40-127.

Nikkanen, T. and Ruotsalainen, S. 2000. Variation in flowering abundance and its impact on the genetic diversity of the seed crop in a Norway spruce seed orchard. Silva Fenn. 34(3): 205-222. doi: http://dx.doi.org/10.14214/sf.626

Ratnam, W., Rajora, O.P., Finkeldey, R., Aravanopoulos, F., Bouvet, J-M., Vaillancourt, R.E., Kanashiro, M., Fady, B., Tomita, M. and Vinson, C. 2014. Genetic effects of forest management practices: Global synthesis and perspectives. For. Ecol. Manage. 333: 52-65. doi:10.1016/j.foreco.2014.06.008 
Reich, P.B., Oleksyn, J. and Tjoelker, M.G. 1994. Seed mass effects on germination and growth of diverse European Scots pine populations. Can. J. For. Res. 24(2):306-320.

Roach, D.A. and Wulff, R.D. 1987. Maternal effects in plants. Ann. Rev. Ecol. Syst. 18: 209235.

Rosenberg, O, Almqvist, C. and Weslin, J. 2012. Systematic insecticide and gibberellin reduced cone damage and increased flowering in a spruce seed orchard. J. Econ.Entomol. 105(3): 916-922. doi: http://dx.doi.org/10.1603/EC11388

Ruotsalainen, S. and Nikkanen, T. 1989. Variation in flowering of north Finnish clones in a Norway spruce seed orchard in Central Finland. In: Stener, L-G. \& Werner, M. (Eds.). 1989. Norway spruce; Provenances, breeding and genetic conservation. Proceedings of the IUFRO working party meeting S2.02-11. Sweden 1988. The Institute for Forest Improvement, report No; 11. Uppsala 1989. pp. 176-188.

Saarsalmi, A., Savonen E-M., Nikkanen, T., Lipas, E. and Mikola, J. 1994. Effect of fertilization on flowering and seed crop in Scots pine seed orchards. Silva Fenn. 28(3): 155176.

Simak, M. 1955. Insect damages on seeds of Norway spruce determined by X-ray photography. Meddelanden från statens skogforskningsinstitut. Serien uppsatser nr 41 .

Sorensen, FC. \& Franklin, JF. 1977. Influence of year of cone collection on seed weight and cotyledon number in Abies procera. Silvae Gen. 26(1): 41-43. 
Sorensen, FC. and Campbell, RK. 1993. Seed weight - seedling size correlation in coastal Douglas-fir: genetic and environmental components. Can. J. For. Res. 23(3): 275-285.

Stoehr, M.U. and Farmer, R.E. Jr. 1986. Genetic and environmental variance in cone size, see yield, and germination properties of black spruce clones. Can. J. For. Res. 16: 1149-1151.

Swedish Statistical Yearbook of Forestry. 2014. Skogsstyrelsen. ISBN 978-91-87535-05-5, www.skogsstyrelsen.se/statistics. $370 \mathrm{p}$.

Venäläinen, A., Tuomenvirta, H., Pirinen, P. and Drebs, A. 2005. A basic Finnish climate data se 1961-2000 - Description and illustrations. Finnish Meteorological Institute. Reports No. 2005:5. Helsinki. 27 p.

VSN International. 2012. GenStat for Windows 15th Edition. VS N International, Hemel Hempstead, UK.

von Weissenberg, K. 1981. Taimitarhakasvatuksen ja -lajittelun vaikutukset metsien geneettisiin ominaisuuksiin. Julkaisussa: Taimitarha-aineiston geneettisen ominaisuudet: tutkimuspäivän 1981 esitelmät. Suonenjoen tutkimusasema. Metsäntutkimuslaitoksen tiedonantoja 34. pp. 15-40.

Wiersma, N. 1973. The importance of insect damage to Norway spruce (Picea abies L.) cones for seed processing. In: Machaníšek, J. 1973. Economic collection of cones of forest 
conifers on the basis of preceding estimation of cone crop. IUFRO Working party: S2.01.06. pp. 119-122. 
Table 1. Height, diameter and age, both determined at breast height $(1.3 \mathrm{~m})$, of individual Norway spruce trees used for cone collection in a forest stand in central Finland. Cone and seed water content (on fresh weight basis) are calculated averages ( \pm standard error of the mean) of measurements from three cones in each tree at time of the cone collection March 14, 2011.

\begin{tabular}{cccccc}
\hline \multirow{2}{*}{ Tree } & Height, $\mathbf{m}$ & $\begin{array}{c}\text { Diameter } \\
(\mathbf{1 . 3 m}), \mathbf{c m}\end{array}$ & Age, a & \multicolumn{2}{c}{ Water content, \% $( \pm \mathbf{S E})$} \\
& & 68 & 165 & $23.1( \pm 0.30)$ & $11.2( \pm 0.17)$ \\
\hline 1 & 29.5 & 53 & 129 & $23.1( \pm 0.25)$ & $11.4( \pm 0.04)$ \\
2 & 27.0 & 46 & 154 & $25.2( \pm 0.23)$ & $12.9( \pm 0.74)$ \\
3 & 24.5 & 41 & 90 & $20.9( \pm 0.37)$ & $10.8( \pm 0.15)$ \\
4 & 24.0 & 45 & 124 & $21.6( \pm 0.35)$ & $10.6( \pm 0.12)$ \\
5 & 24.5 & 38 & 133 & $21.9( \pm 0.30)$ & $10.6( \pm 0.44)$ \\
6 & 25.0 & 51 & 135 & $21.8( \pm 0.13)$ & $10.9( \pm 0.17)$ \\
7 & 27.5 & & & &
\end{tabular}


Table 2. Origin of the clones used for cone collection in a Norway spruce seed orchard in central Finland. Cone and seed water content (on fresh weight basis) are calculated averages ( \pm standard error of the mean) of measurements from three cones in each clone / graft at the time of collection, January 14, 2013.

\begin{tabular}{|c|c|c|c|c|}
\hline \multirow{2}{*}{$\begin{array}{l}\text { Clone } \\
\text { number }\end{array}$} & \multicolumn{2}{|c|}{ Plustree origin } & \multicolumn{2}{|c|}{ Water content, \% ( \pm SE) } \\
\hline & Municipality & Co-ordinates & Cone & Seed \\
\hline E11 & Miehikkälä & $60^{\circ} 45^{\prime} \mathrm{N}, 27^{\circ} 30^{\prime} \mathrm{E}$ & $29.0( \pm 1.34)$ & $20.7( \pm 1.38)$ \\
\hline E246 & Somero & $60^{\circ} 42^{\prime} \mathrm{N}, 23^{\circ} 30^{\prime} \mathrm{E}$ & 29.8. $( \pm 0.64)$ & $19.5( \pm 0.15)$ \\
\hline E252 & Mäntsälä & $60^{\circ} 40^{\prime} \mathrm{N}, 25^{\circ} 20^{\prime} \mathrm{E}$ & $25.5( \pm 0.38)$ & $17.7( \pm 0.54)$ \\
\hline E456D & litti & $60^{\circ} 45^{\prime} \mathrm{N}, 26^{\circ} 25^{\prime} \mathrm{E}$ & $26.8( \pm 0.61)$ & $19.1( \pm 2.10)$ \\
\hline E1549 & Pöytyä & $60^{\circ} 43^{\prime} \mathrm{N}, 22^{\circ} 51^{\prime} \mathrm{E}$ & $28.6( \pm 0.87)$ & $19.5( \pm 0.36)$ \\
\hline
\end{tabular}


Table 3. Observed proportions (\%) of different quality seed extracted from cones collected from seven Norway spruce trees in central Finland, total number of seeds evaluated in each tree and p-value of tree (genotype) effect on the proportion of seed in each quality class.

\begin{tabular}{|c|c|c|c|c|c|c|c|c|}
\hline \multicolumn{9}{|c|}{ Tree } \\
\hline & 1 & 2 & 3 & 4 & 5 & 6 & 7 & $\begin{array}{l}\text { Tree effect, } \\
\text { P-value }\end{array}$ \\
\hline Full & 29.2 & 56.4 & 60.3 & 56.7 & 84.5 & 86.4 & 64.7 & $<0.001$ \\
\hline Empty & 59.3 & 35.2 & 29.5 & 24.1 & 9.9 & 8.0 & 32.8 & $<0.001$ \\
\hline Immature & 3.1 & 0 & 0.7 & 0.9 & 0.3 & 1.1 & 0.8 & 0.002 \\
\hline Severely immature & 2.7 & 0 & 0.6 & 1.3 & 0.1 & 0 & 0.4 & 0.002 \\
\hline $\begin{array}{l}\text { Development } \\
\text { stagnated }\end{array}$ & 2.5 & 0 & 0 & 0.6 & 0.2 & 0.3 & 0.1 & 0.029 \\
\hline $\begin{array}{c}\text { Cydia strobilella } \\
\text { damage }\end{array}$ & 2.1 & 0.1 & 6.9 & 0.3 & 0.5 & 1.8 & 0.1 & 0.006 \\
\hline $\begin{array}{c}\text { Megastigmus } \\
\text { strobilobius larva }\end{array}$ & 0.2 & 8.0 & 0.9 & 14.5 & 3.8 & 0.7 & 0.3 & $<0.001$ \\
\hline $\begin{array}{c}\text { Plemeliella } \\
\text { abietina larva }\end{array}$ & 0 & 0 & 0.6 & 0 & 0.3 & 0 & 0.3 & test not possible ${ }^{*}$ \\
\hline $\begin{array}{l}\text { Mechanical } \\
\text { damage }\end{array}$ & 0.1 & 0.2 & 0 & 1.1 & 0 & 1.2 & 0.1 & 0.175 \\
\hline $\begin{array}{l}\text { Unidentified } \\
\text { damage }\end{array}$ & 0.8 & 0.1 & 0.4 & 0.6 & 0.4 & 0.5 & 0.4 & test not possible* \\
\hline $\begin{array}{c}\text { Total number of } \\
\text { seed }\end{array}$ & 891 & 855 & 691 & 698 & 1127 & 941 & 1153 & \\
\hline
\end{tabular}


Table 4. Observed proportions (\%) of different quality seed extracted from cones collected from five clones in a Norway spruce seed orchard (Sv 403) in central Finland, total number of seeds evaluated in each clone and p-value of clone effect on the proportion of seed in each quality class.

\begin{tabular}{|c|c|c|c|c|c|c|}
\hline \multicolumn{7}{|c|}{ Clone } \\
\hline & E11 & E246 & E252 & E456D & E1549 & $\begin{array}{c}\text { Clone effect, } P \text { - } \\
\text { value }\end{array}$ \\
\hline Full & 63.8 & 63.9 & 79.2 & 79.1 & 33.2 & $<0.001$ \\
\hline Empty & 25.7 & 20.7 & 8.6 & 14.6 & 52.0 & $<0.001$ \\
\hline Immature & 0.6 & 0.5 & 0.2 & 0.1 & 0.3 & 0.427 \\
\hline $\begin{array}{l}\text { Severely } \\
\text { immature }\end{array}$ & 0.1 & 0.5 & 0 & 0 & 0 & 0.712 \\
\hline $\begin{array}{l}\text { Development } \\
\text { stagnated }\end{array}$ & 0.5 & 0.3 & 0.2 & 0 & 0 & 0.574 \\
\hline $\begin{array}{l}\text { Cydia strobilella } \\
\text { damage }\end{array}$ & 6.2 & 8.6 & 10.7 & 3.3 & 11.3 & 0.118 \\
\hline $\begin{array}{c}\text { Megastigmus } \\
\text { strobilobius larva }\end{array}$ & 0 & 0 & 0 & 0 & 0 & - \\
\hline $\begin{array}{c}\text { Plemeliella } \\
\text { abietina larva }\end{array}$ & 0 & 0 & 0 & 0 & 0 & - \\
\hline $\begin{array}{l}\text { Mechanical } \\
\text { damage }\end{array}$ & 1.1 & 2.2 & 0.7 & 1.6 & 0.4 & 0.138 \\
\hline $\begin{array}{l}\text { Unidentified } \\
\text { damage }\end{array}$ & 2.0 & 3.3 & 0.4 & 1.4 & 2.3 & 0.023 \\
\hline $\begin{array}{c}\text { Total number of } \\
\text { seed }\end{array}$ & 991 & 970 & 1215 & 1159 & 922 & \\
\hline
\end{tabular}


Table 5. Average observed seed weight $(\mathrm{mg})( \pm \mathrm{SE})$ of different quality seed in seven individual Norway spruce trees in central Finland and the p-value of the clone effect on the seed weight in each quality class.

\begin{tabular}{|c|c|c|c|c|c|c|c|c|}
\hline \multicolumn{9}{|c|}{ Tree } \\
\hline & 1 & 2 & 3 & 4 & 5 & 6 & 7 & $\begin{array}{c}\text { Tree effect, } \\
\text { P-value }\end{array}$ \\
\hline Full & $\begin{array}{c}6.12 \\
( \pm 0.049)\end{array}$ & $\begin{array}{c}6.09 \\
( \pm 0.034)\end{array}$ & $\begin{array}{c}5.22 \\
( \pm 0.030)\end{array}$ & $\begin{array}{c}6.51 \\
( \pm 0.037)\end{array}$ & $\begin{array}{c}5.60 \\
( \pm 0.021)\end{array}$ & $\begin{array}{c}5.368 \\
( \pm 0.029)\end{array}$ & $\begin{array}{c}6.37 \\
( \pm 0.029)\end{array}$ & $<0.001$ \\
\hline Empty & $\begin{array}{c}1.40 \\
( \pm 0.020)\end{array}$ & $\begin{array}{c}1.89 \\
( \pm 0.038)\end{array}$ & $\begin{array}{c}1.57 \\
( \pm 0.026)\end{array}$ & $\begin{array}{c}1.86 \\
( \pm 0.039)\end{array}$ & $\begin{array}{c}1.61 \\
( \pm 0.029)\end{array}$ & $\begin{array}{c}1.49 \\
( \pm 0.082)\end{array}$ & $\begin{array}{c}1.61 \\
( \pm 0.041)\end{array}$ & $<0.001$ \\
\hline Immature & $\begin{array}{c}4.34 \\
( \pm 0.126)\end{array}$ & - & $\begin{array}{c}3.74 \\
( \pm 0.079)\end{array}$ & $\begin{array}{c}4.55 \\
( \pm 0.238)\end{array}$ & $\begin{array}{c}3.92 \\
( \pm 0.707)\end{array}$ & $\begin{array}{c}4.29 \\
( \pm 0.347)\end{array}$ & $\begin{array}{c}5.05 \\
( \pm 0.190)\end{array}$ & 0.038 \\
\hline Severely immature & $\begin{array}{c}3.01 \\
( \pm 0.118)\end{array}$ & - & $\begin{array}{c}2.972 \\
( \pm 0.293)\end{array}$ & $\begin{array}{c}3.68 \\
( \pm 0.211)\end{array}$ & $3.00(0)^{*}$ & - & $\begin{array}{c}3.78 \\
( \pm 0.376)\end{array}$ & 0.026 \\
\hline $\begin{array}{l}\text { Development } \\
\text { stagnated }\end{array}$ & $\begin{array}{c}2.76 \\
( \pm 0.095)\end{array}$ & - & - & $\begin{array}{c}2.71 \\
( \pm 0.550)\end{array}$ & $\begin{array}{c}2.43 \\
( \pm 0.314)\end{array}$ & $\begin{array}{c}1.51 \\
( \pm 0.522)\end{array}$ & $2.85(0)^{*}$ & 0.005 \\
\hline $\begin{array}{c}\text { Cydia strobilella } \\
\text { damage }\end{array}$ & $\begin{array}{c}3.46 \\
( \pm 0.228)\end{array}$ & $2.40(0)^{*}$ & $\begin{array}{c}3.26 \\
( \pm 0.089)\end{array}$ & $\begin{array}{c}5.40 \\
( \pm 1.218)\end{array}$ & $\begin{array}{c}2.94 \\
( \pm 0.707)\end{array}$ & $\begin{array}{c}3.46 \\
( \pm 0.198)\end{array}$ & $3.12(0)^{*}$ & 0.007 \\
\hline $\begin{array}{c}\text { Megastigmus } \\
\text { strobilobius larva }\end{array}$ & $\begin{array}{c}2.76 \\
( \pm 0.354)\end{array}$ & $\begin{array}{c}3.19 \\
( \pm 0.124)\end{array}$ & $\begin{array}{c}2.44 \\
( \pm 0.194)\end{array}$ & $\begin{array}{c}3.50 \\
( \pm 0.081)\end{array}$ & $\begin{array}{c}3.00 \\
( \pm 0.108)\end{array}$ & $\begin{array}{c}2.59 \\
( \pm 0.117)\end{array}$ & $\begin{array}{c}2.67 \\
( \pm 0.327)\end{array}$ & $<0.001$ \\
\hline $\begin{array}{c}\text { Plemeliella } \\
\text { abietina larva }\end{array}$ & - & - & $\begin{array}{c}2.90 \\
( \pm 0.280)\end{array}$ & - & $\begin{array}{c}2.68 \\
( \pm 0.117)\end{array}$ & - & $\begin{array}{c}2.28 \\
( \pm 0.114)\end{array}$ & 0.197 \\
\hline $\begin{array}{l}\text { Mechanical } \\
\text { damage }\end{array}$ & $1.91(0)^{*}$ & $\begin{array}{c}4.26 \\
( \pm 2.118)\end{array}$ & - & $\begin{array}{c}2.66 \\
( \pm 0.492)\end{array}$ & - & $\begin{array}{c}2.48 \\
( \pm 0.306)\end{array}$ & $0.55(0)^{*}$ & 0.268 \\
\hline $\begin{array}{l}\text { Unidentified } \\
\text { damage }\end{array}$ & $\begin{array}{c}3.40 \\
( \pm 0.677)\end{array}$ & $3.59(0)^{*}$ & $\begin{array}{c}5.161 \\
( \pm 0.323)\end{array}$ & $\begin{array}{c}5.89 \\
( \pm 0.265)\end{array}$ & $\begin{array}{c}5.64 \\
( \pm 0.332)\end{array}$ & $\begin{array}{c}4.23 \\
( \pm 0.437)\end{array}$ & $\begin{array}{c}5.42 \\
( \pm 0.318)\end{array}$ & 0.011 \\
\hline
\end{tabular}


Table 6. Average observed seed weight $(\mathrm{mg})( \pm \mathrm{SE})$ of different quality seed in five clones in a Norway spruce seed orchard in central Finland and the p-value of the clone effect on the seed weight in each quality class.

\begin{tabular}{|c|c|c|c|c|c|c|}
\hline \multicolumn{7}{|c|}{ Clone } \\
\hline & E11 & E246 & E252 & E456D & E1549 & $\begin{array}{c}\text { Clone effect, } \mathrm{P} \text { - } \\
\text { value }\end{array}$ \\
\hline Full & $\begin{array}{c}6.66 \\
( \pm 0.039)\end{array}$ & $\begin{array}{c}5.54 \\
( \pm 0.029)\end{array}$ & $\begin{array}{c}6.76 \\
( \pm 0.025)\end{array}$ & $\begin{array}{c}6.25 \\
( \pm 0.023)\end{array}$ & $\begin{array}{c}6.39 \\
( \pm 0.050)\end{array}$ & $<0.001$ \\
\hline Empty & $\begin{array}{c}2.49 \\
( \pm 0.038)\end{array}$ & $\begin{array}{c}1.69 \\
( \pm 0.026)\end{array}$ & $\begin{array}{c}2.07 \\
( \pm 0.054)\end{array}$ & $\begin{array}{c}1.94 \\
( \pm 0.034)\end{array}$ & $\begin{array}{c}2.36 \\
( \pm 0.014)\end{array}$ & $<0.001$ \\
\hline Immature & $\begin{array}{c}5.85 \\
( \pm 0.324)\end{array}$ & $\begin{array}{c}3.71 \\
( \pm 0.104)\end{array}$ & $\begin{array}{c}4.97 \\
( \pm 0.623)\end{array}$ & $\begin{array}{l}6.03 \\
(0)^{*}\end{array}$ & $\begin{array}{c}5.50 \\
( \pm 0.624)\end{array}$ & 0.006 \\
\hline Severely immature & $\begin{array}{l}5.18 \\
(0)^{*}\end{array}$ & $\begin{array}{c}3.63 \\
( \pm 0.375)\end{array}$ & - & - & - & 0.167 \\
\hline $\begin{array}{l}\text { Development } \\
\text { stagnated }\end{array}$ & $\begin{array}{c}2.77 \\
( \pm 0.124)\end{array}$ & $\begin{array}{c}2.69 \\
( \pm 0.929)\end{array}$ & $\begin{array}{c}3.59 \\
( \pm 0.939)\end{array}$ & - & $\begin{array}{c}3.26 \\
( \pm 0.358)\end{array}$ & 0.632 \\
\hline $\begin{array}{c}\text { Cydia strobilella } \\
\text { damage }\end{array}$ & $\begin{array}{c}4.68 \\
( \pm 0.218)\end{array}$ & $\begin{array}{c}3.78 \\
( \pm 0.123)\end{array}$ & $\begin{array}{c}4.38 \\
( \pm 0.075)\end{array}$ & $\begin{array}{c}4.45 \\
( \pm 0.236)\end{array}$ & $\begin{array}{c}4.28 \\
( \pm 0.082)\end{array}$ & $<0.001$ \\
\hline $\begin{array}{c}\text { Megastigmus } \\
\text { strobilobius larva }\end{array}$ & - & - & & - & - & - \\
\hline $\begin{array}{c}\text { Plemeliella } \\
\text { abietina larva }\end{array}$ & - & - & & - & - & - \\
\hline $\begin{array}{l}\text { Mechanical } \\
\text { damage }\end{array}$ & $\begin{array}{c}4.27 \\
( \pm 0.662)\end{array}$ & $\begin{array}{c}3.87 \\
( \pm 0.377)\end{array}$ & $\begin{array}{c}5.33 \\
( \pm 0.518)\end{array}$ & $\begin{array}{c}4.04 \\
( \pm 0.455)\end{array}$ & $\begin{array}{c}3.36 \\
( \pm 1.407)\end{array}$ & 0.387 \\
\hline $\begin{array}{c}\text { Unidentified } \\
\text { damage }\end{array}$ & $\begin{array}{c}5.85 \\
( \pm 0.510)\end{array}$ & $\begin{array}{c}4.53 \\
( \pm 0.253)\end{array}$ & $\begin{array}{c}6.43 \\
( \pm 0.340)\end{array}$ & $\begin{array}{c}5.79 \\
( \pm 0.385)\end{array}$ & $\begin{array}{c}5.62 \\
( \pm 0.222)\end{array}$ & 0.007 \\
\hline
\end{tabular}

- no observation

* only one observation 
Table 7. Variance component estimates of seed weight between individual trees, between cones (within the same tree) and within cones. The proportion of variance of each of these components is compared to the total variance in seed weight. The cones were collected from seven trees in a Norway spruce stand in central Finland.

\begin{tabular}{cccc}
\hline Term & Variance estimate & SE & Proportion, \% \\
\hline All seed & & & \\
Intertree & 0.4910 & 0.3080 & 11.3 \\
Intercone & 0.1530 & 0.0530 & 3.5 \\
Intracone & 3.6830 & 0.0650 & 85.1 \\
& & & \\
Full seed (>2.5 mg) & & & \\
Intertree & 0.1949 & 0.1314 & 28.6 \\
Intercone & 0.1250 & 0.0395 & 18.3 \\
Intracone & 0.3620 & 0.0081 & 53.0 \\
Empty seed & & & \\
Intertree & 0.0277 & 0.0200 & 7.4 \\
Intercone & 0.0199 & 0.0082 & 5.3 \\
Intracone & 0.3280 & 0.0111 & 87.3 \\
\hline
\end{tabular}


Table 8. Variance component estimates of seed weight between clones, between cones (within the same clone) and within cones. The proportion of variance of each of these components is compared with the total variance in seed weight. The cones were collected from five clones in a Norway spruce seed orchard in central Finland.

\begin{tabular}{cccc}
\hline Term & Variance estimate & SE & Proportion, \% \\
\hline All seed & & & \\
Intertree & 0.6870 & 0.5070 & 17.1 \\
Intercone & 0.1090 & 0.0440 & 2.7 \\
Intracone & 3.2150 & 0.0630 & 80.2 \\
& & & \\
Full seed (>2.5mg) & & & \\
Intertree & 0.2164 & 0.1924 & 24.3 \\
Intercone & 0.2138 & 0.0793 & 24.0 \\
Intracone & 0.4610 & 0.0112 & 51.7 \\
Empty seed & & & \\
Intertree & 0.0948 & 0.0715 & 32.9 \\
Intercone & 0.0215 & 0.0090 & 7.5 \\
Intracone & 0.1720 & 0.0071 & 59.7 \\
\hline
\end{tabular}



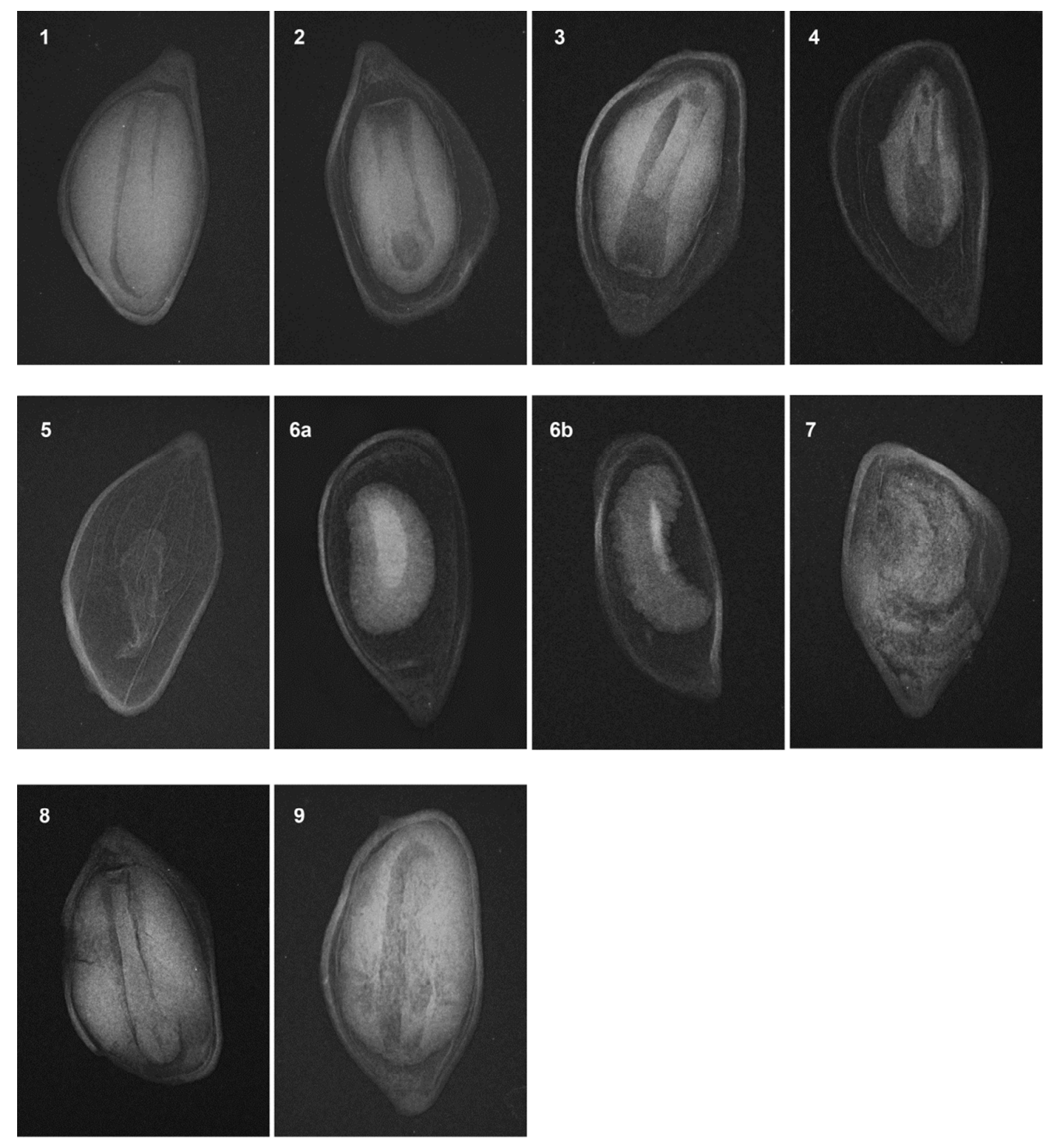

Figure 1. Norway spruce seed quality classes according to radiography. 1-full, 2- anatomically immature, 3-severely anatomically immature, 4-development stagnated, 5-empty, 6a- Megastigmus strobilobius larvae, 6b-Plemeliella abietina larvae, 7-Cydia strobilella damage, 8-mechanically damaged, 9-unidentified damage. 


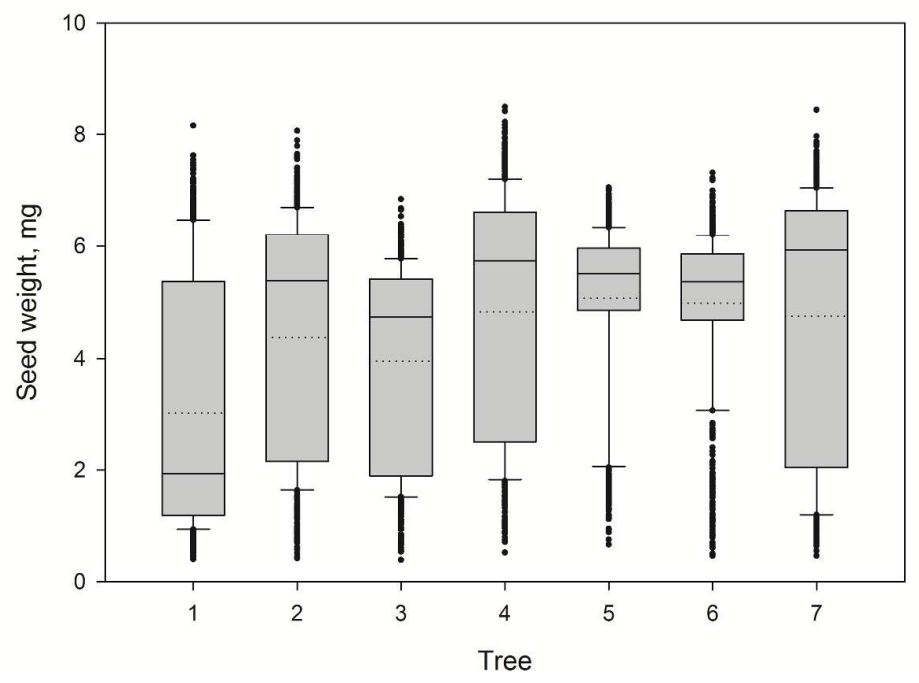

Figure 2. Box plot of seed weights of Norway spruce seeds collected from a forest stand in central Finland. Each seed from five cones from each tree was individually weighed. The box includes $50 \%$ of the observations and the whiskers indicate the $90^{\text {th }}$ and $10^{\text {th }}$ percentiles. The solid line inside the box indicates the median and the dashed line the mean. 


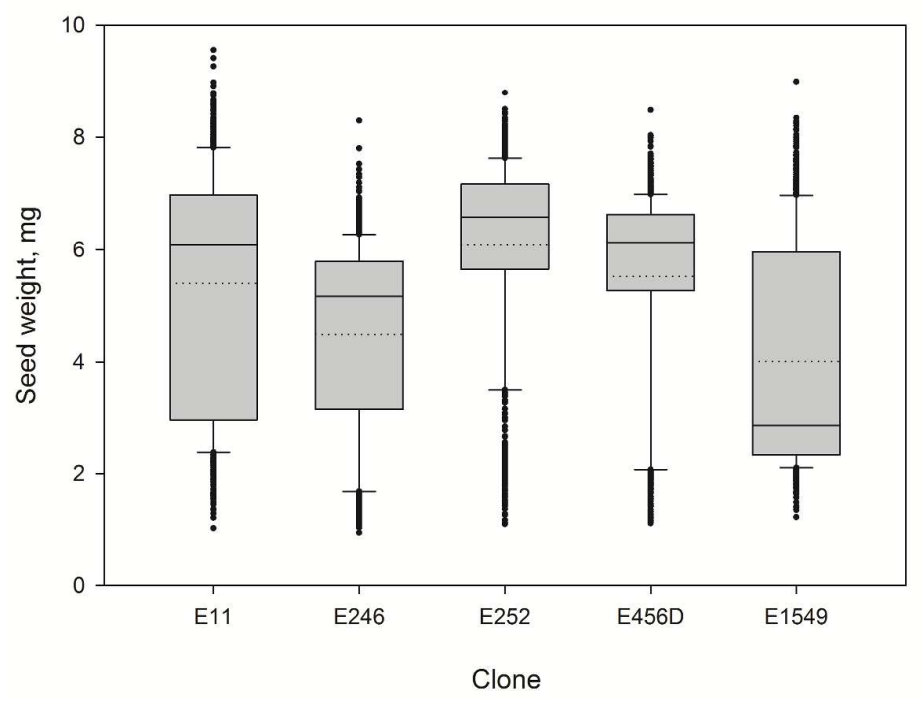

Figure 3. Range of seed weights of Norway spruce seeds collected from a seed orchard located in central Finland. Each seed from four cones from each clone was individually weighed. The box includes $50 \%$ of the observations and the whiskers indicate the $90^{\text {th }}$ and $10^{\text {th }}$ percentiles. The solid line inside the box indicates the median and the dashed line the mean. 